\title{
Identification of the Causes of a Landslide in Koronowo (Polish Lowlands)
}

\author{
Lesław Zabuski, Marek Kulczykowski, Waldemar Świdziński \\ Institute of Hydro-Engineering, Polish Academy of Sciences, 7 Kościerska, 80-328 Gdańsk, Poland, \\ e-mail: leslawzabuski@ibwpan.gda.pl
}

(Received July 10, 2019; revised October 14, 2019)

\begin{abstract}
The paper discusses difficulties of identifying the causes of a landslide. These difficulties are illustrated in the example of a catastrophic landslide on the embankment of the western bank of the Brda River, which affected a bridge abutment of a disused narrow-gauge railway line from Bydgoszcz to Koronowo (Polish Lowlands). The railway was closed in 1992, and after the removal of the track, the bridge served as a pedestrian overpass. The landslide occurred in February 2011. Investigations revealed that the first signs of the landslide were cracks and subsidence that appeared at the embankment crest. Then, an initially slow movement accelerated suddenly, resulting in an over $45 \mathrm{~m}$ total displacement of the soil mass. The primary passive cause of the landslide movement resulted from the geology of the mass (loose soils underlain by cohesive soils) and from the steep inclination of the embankment surface. Active causes, however, are often ambiguous. In this case, no significant apparent phenomena which could trigger the movement occurred in the days preceding its initiation. Therefore, a detailed analysis of atmospheric conditions was carried out to identify and explain the causes. It was proved that the fundamental triggering cause of the landslide was a combination of rainfall, snowfall, snow-melting and air temperature. Moreover, an important cause was a faulty construction of a ditch with a sewage pipe on the crest of the embankment.
\end{abstract}

Key words: landslide causes, landslide development, atmospheric conditions, faulty construction

\section{Introduction}

The paper presents the results of an analysis of the causes and effects of a landslide that developed on the western bank of the Brda River in the immediate vicinity of a bridge abutment of a closed narrow-gauge railway line near Koronowo in central Poland (Fig. 1), (Zabuski et al 2011, 2013, 2015; Kulczykowski et al 2014).

The historical bridge (Fig. 2), built in 1895, is protected by Polish law as an engineering monument. The railway was used for passenger transportation until 1969 and

(C) 2019 Institute of Hydro-Engineering of the Polish Academy of Sciences. This is an open access article licensed under the Creative Commons Attribution-NonCommercial-NoDerivs License (http://creativecommons.org/licenses/by-nc-nd/3.0/). 


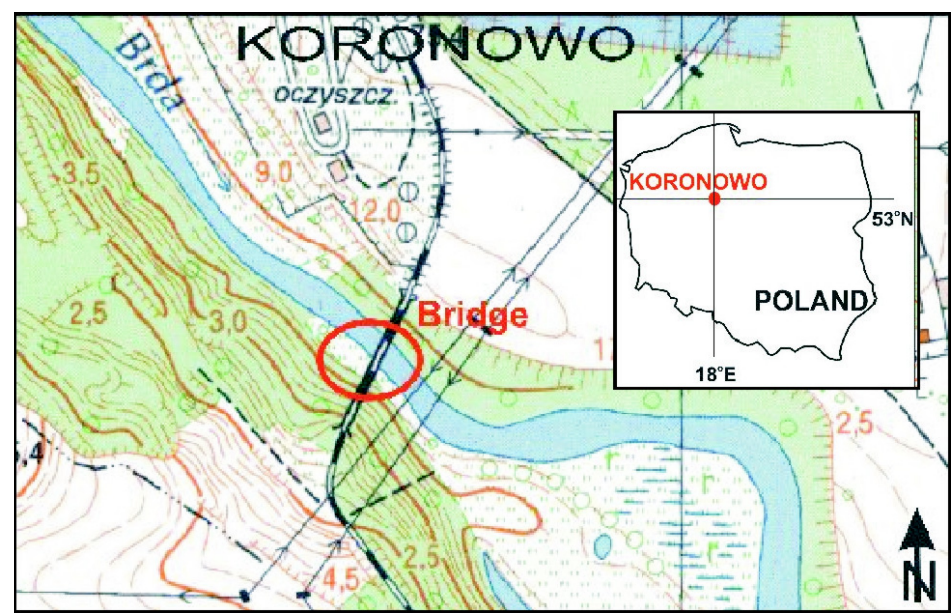

Fig. 1. Location of the study area

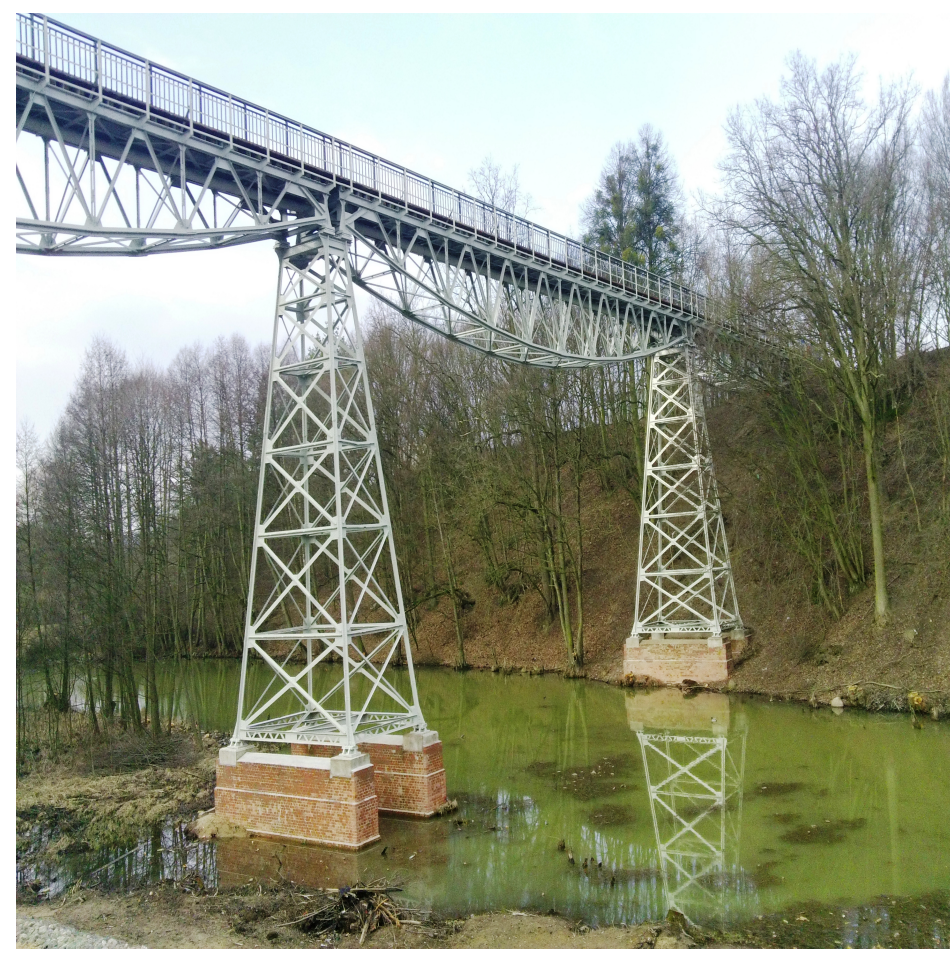

Fig. 2. Historical narrow-gauge railway bridge on the Brda River

for transportation of freight until 1992. In 2005, a trench was excavated in the crown of the embankment to accommodate a sewage collector. Then the bridge served as a pedestrian overpass until the landslide, which damaged the embankment and thus prevented further use of the bridge in that capacity (Figs. 3a and 3b). 
a)

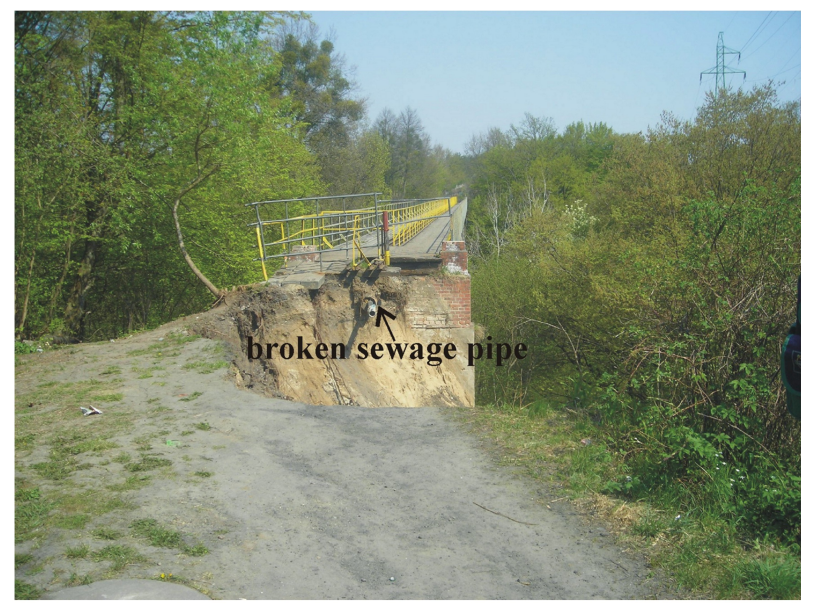

b)

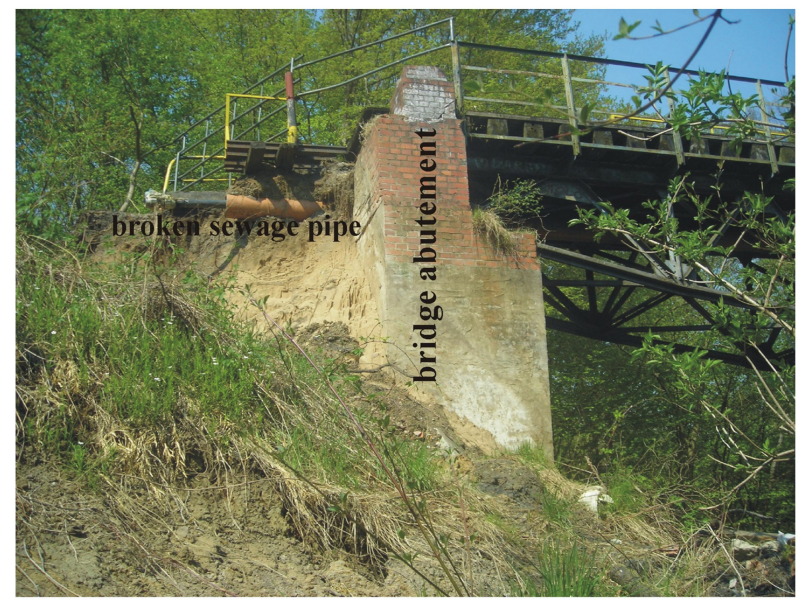

Fig. 3. Landslide at the bridge: a) scarp of the landslide, b) bridge abutment and a broken sewage pipe

The discontinuation of railway traffic eliminated dynamic impact generated by trains. The earlier multi-year loading had resulted in good consolidation of the embankment soil. Therefore, the landslide was unexpected and defied straightforward explanation. It should be pointed out that the passive and active causes of a landslide are in most cases relatively easy to discover and explain (Berry et al 2004, Chirica and Galer 1998, Bromhead and Ibsen 2007). In some cases, however, the causes of these phenomena are difficult or even impossible to determine and understand.

In the vicinity of Koronowo, landslide susceptibility results from geologic conditions (glacial deposits resting over impermeable Miocene clays) and the geomorphological setting (relatively steep slopes of the Brda River valley). Particularly unstable are configurations where loose granular soils rest on cohesive layers which are almost impermeable (Vassalo et al 2015, Bernardie et al 2015). Such an arrangement of layers occurs at the site in question, where water-saturated, highly plastic or 
semi-liquid soil forms a slip zone. Usually more important are active factors, such as stormy or long-lasting precipitation, snow melting, natural or artificial undercutting, rising water in a watercourse or a reservoir at the base of the slope, dynamic factors and additional loading. However, in the case of the landslide described here a simple analysis of causes did not yield a clear answer, and a more sophisticated approach was necessary. The aim of the study was to fully elucidate the relationship between passive causes, such as the geological structure of the massif, and the influence of atmospheric conditions on landslide initiation and progression (triggering factors of the landslide), and, above all, to explain the delay (of 3-4 months) between a period of extreme rainfall (November-December) and landslide initiation (February).

\section{Geology of the Study Area}

The geologic setting is in the range of thick deposits related to the North Polish Glaciations (Słowiński et al 2015). Fluvioglacial sands and gravels represent the Hrubieszów interstadial, while the main stadial is represented by glacial till, fluvioglacial sand and gravel or glacilacustrine muds. The deposits are exposed in the eastern part of Koronowo. In the western part, glacial tills predominate at the surface. The bottom of the river valley is filled with fluvial sands of flood and overflood terraces. The bottoms of smaller stream valleys are filled with sandy slack-water deposits. Moreover, accumulations of peat and brown coal appear in local depressions. In places, among the Quaternary deposits, a glacial raft composed of sand, mud and brown coal of the Miocene or the Pliocene age has been identified. The thickness of the complexes varies from $2 \mathrm{~m}$ to $30 \mathrm{~m}$ (Listkowska 1988). The upper face of the clay and mud complexes interlaced with brown coal occurs at a depth ranging from $35.5 \mathrm{~m}$ to $1.6-16 \mathrm{~m}$ in the northern part of the study area. The valley sides are largely covered with colluvial material.

\section{Observational Method and Results of Landslide Development}

Since the embankment had been considered stable, no monitoring devices were installed in the slope. Therefore, the first signs of landslide movement, observed on 19 February 2011 in the form of cracks and subsidence at the embankment crest, were a surprise (Zabuski et al 2015, Kulczykowski et al 2014). The initially slow movement suddenly accelerated in the following days, severe deformations occurred on 13 March, and by the end of that month the landslide was almost fully developed. At that time, the landslide was $45 \mathrm{~m}$ long, and its toe was at the level of the river flood terrace (Fig. 4, landslide A). Following the classification of Cruden and Varnes (1996) and Varnes (1978), the landslide has been classified as rotational-translational.

Approximate measurements and detailed observations showed that the rate of displacement decreased with time, from about $1 \mathrm{~m} /$ day in February and March to a few $\mathrm{cm} /$ day in the following months. In parallel, the landslide scarp was enlarging (see Fig. 3), while other morphological features became buried by the displaced soil. 


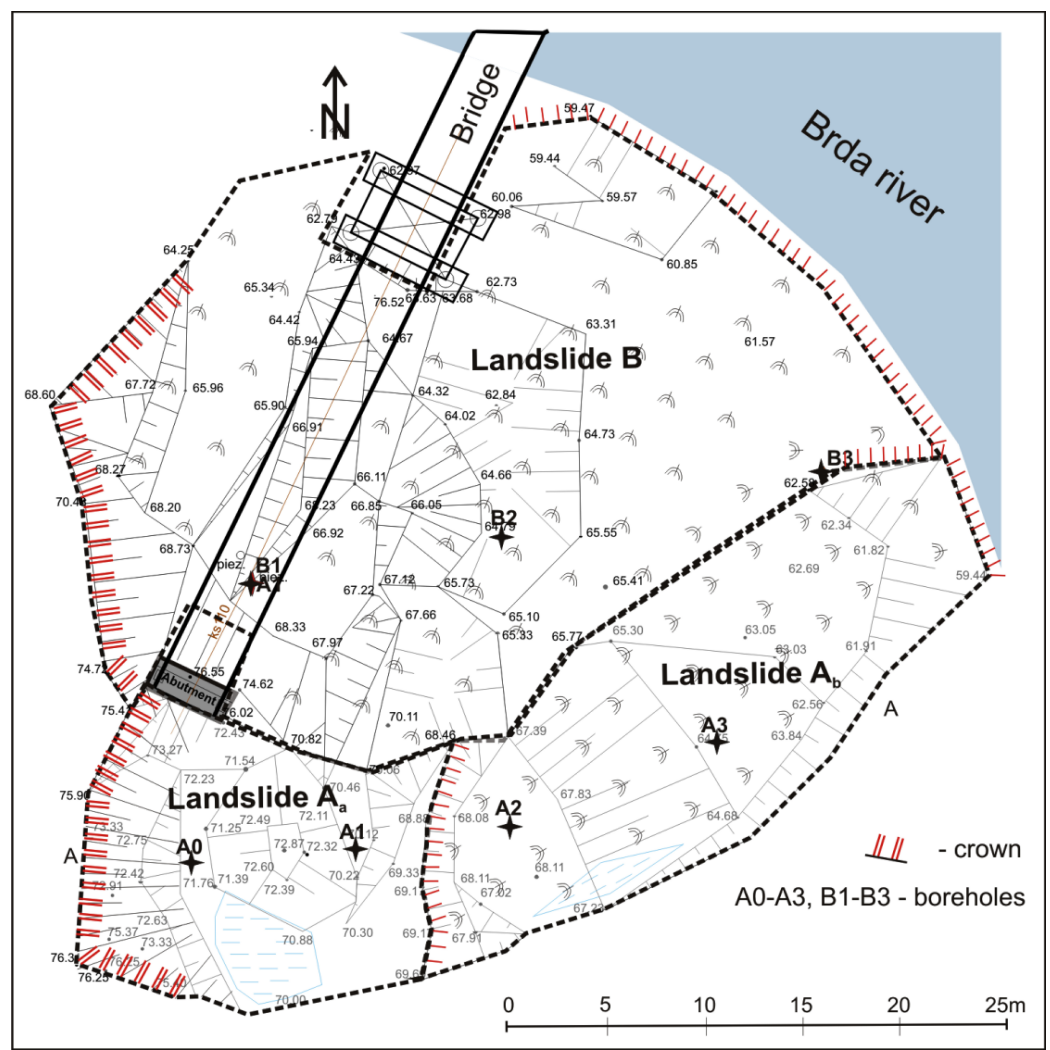

Fig. 4. Parts A and B of the landslide in the vicinity of the bridge

At the same time and later on in 2011, deformations occurred under the bridge, where the slip was directed generally towards the north-east. The resultant exposure of the abutment walls, on both the embankment and bridge sides (Fig. 4, landslide B), was believed to threaten bridge stability. However, the impact of landslide B was not as noticeable as that of landslide A, and therefore only the progression of landslide A was analyzed in details. In this case, 1.2-2.5 m thick non-cohesive soils forming the upper layer of the embankment were underlain by generally impermeable cohesive soils, i.e. clay and occasionally loam. An exemplary borehole log for the analyzed subsoil is shown in Fig. 5.

In each borehole (see Fig. 4), the soil profile and soil properties were determined by penetration tests and vane tests with a Gonor probe. Moreover, undisturbed soil samples were taken as well, specifically at the interface layer between the non-cohesive alluvial soil and the impermeable cohesive layers below. The analysis of the results of such tests carried out in boreholes A1-A3 in the cross-section A-A (Fig. 6) showed similar arrangement and properties of soil layers.

A detailed inspection of the terrain surface revealed that the landslide should be divided into two minor parts, i.e. $A_{a}$ and $A_{b}$, of which the former, upper part $\left(A_{a}\right)$ was 


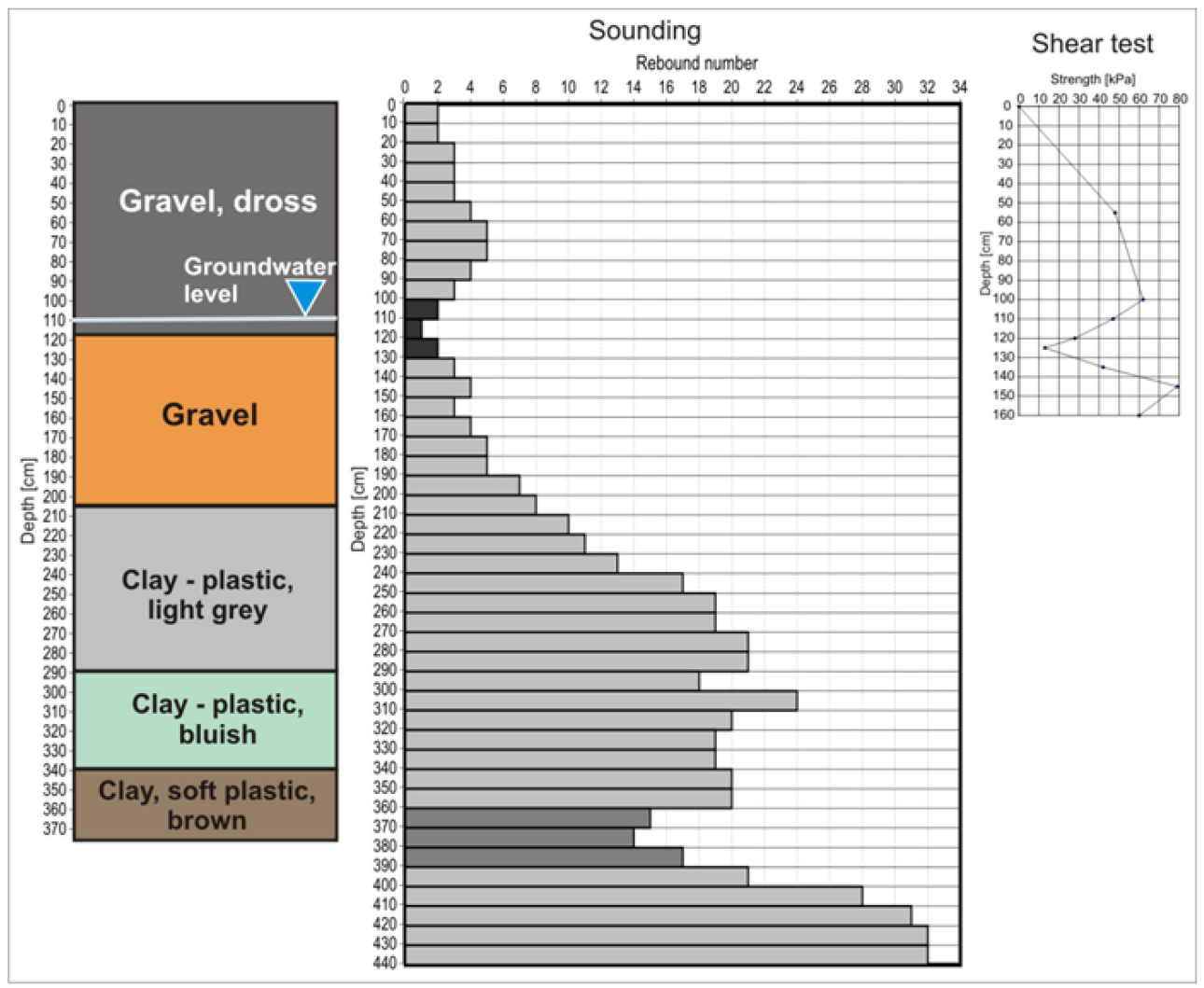

Fig. 5. Example of a soil profile and test results in borehole A0

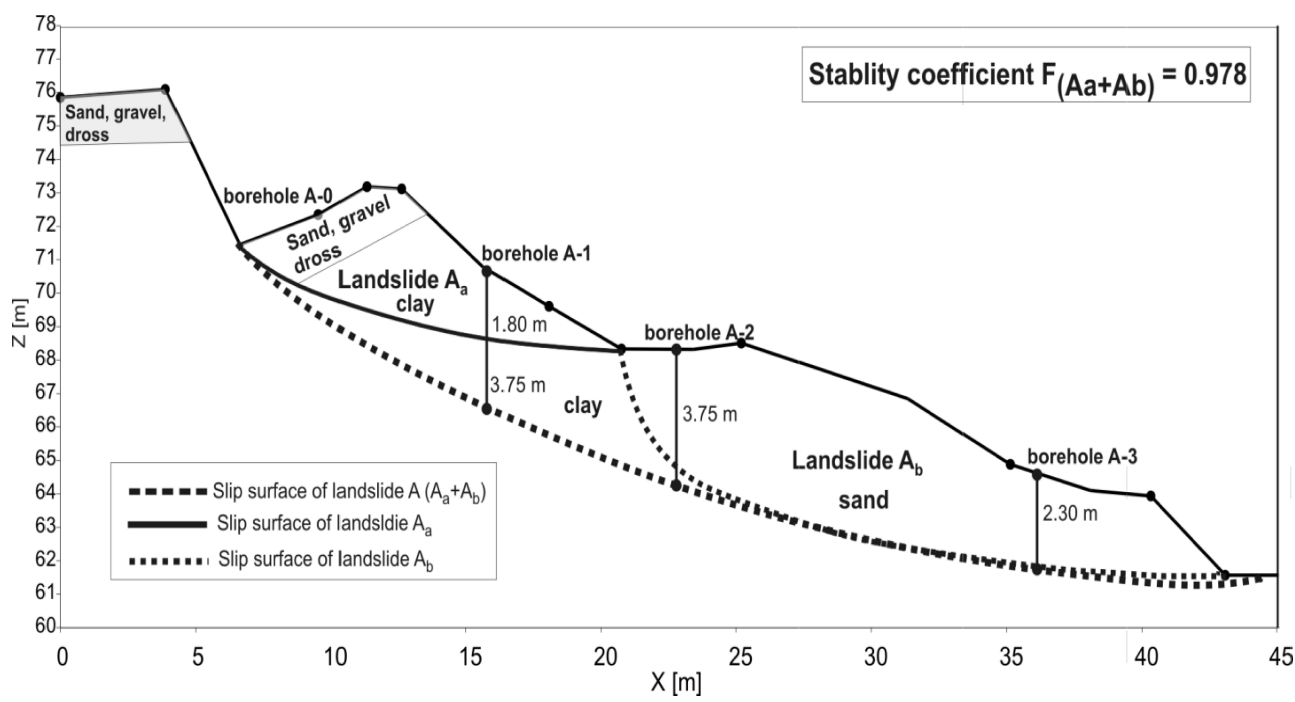

Fig. 6. Landslide A: soil arrangement and the division of the landslide body into minor parts 
mainly composed of clay, whereas the lower $\left(\mathrm{A}_{\mathrm{b}}\right)$ consisted predominantly of sand underlain by clay (see Fig. 6).

Stability calculations performed by the Morgenstern-Price method proved that the whole landslide $\left(\mathrm{A}_{\mathrm{a}}+\mathrm{A}_{\mathrm{b}}\right)$ was most prone to slide. The resultant parameters of the soil (clay and loam) $c=4 \mathrm{kPa}, \varphi=6^{\circ}, \gamma=22 \mathrm{kN} / \mathrm{m}^{3}$ were determined, providing the limit equilibrium state of the slope. It was assumed that, due to the continuous movement, the stability coefficient $F$ should be slightly lower than 1.0 , and thus the calculated coefficient is equal to 0.978 .

\section{Discussion of the Results}

Careful analysis revealed that the causes of the landslide were both passive and active. The former included the relatively steep slope of the embankment and the specific lithology of the soil mass.

Due to the peculiar arrangement of the layers, water percolating through the loose soil cover, when reaching the interface with the cohesive medium, generated an excess of pore pressure and weakened the soil strength parameters. Another cause of this weakening was the increase in soil moisture; these two effects promoted the slip. Slicken surfaces were clearly visible in natural outcrops in the landslide scarp.

However, the identification of triggering (active) factors appeared much more complicated at first glance. No excessive precipitation, snow-melting or any other unfavourable phenomena occurred immediately before the initiation of the movement. To assess the impact of rainfall and melt water on the stability of the embankment, it was necessary to examine the precipitation pattern versus air temperature in the period preceding the failure. According to meteorological data, year 2010 was characterised by extremely high precipitation, significantly exceeding multi-year means $(976 \mathrm{~mm}$ in 2010 versus $727 \mathrm{~mm}$, being the average annual precipitation total in Koronowo in 2004-2011). The sum of November-December precipitation in 2010 was equal to $238 \mathrm{~mm}$, whereas the average precipitation in these two months in 2004-2011 barely exceeded $104 \mathrm{~mm}$.

A detailed combined analysis of the precipitation and temperature data revealed that the period of decisive importance for the landslide generation were the 3-4 months from November 2010 until the failure onset (!). Air temperature in November was positive, and precipitation was significantly higher than average values (Fig.7).

As interception and superficial run-off were close to zero, almost all water infiltrated into the slope mass. Moreover, infiltration was facilitated by the fact that in 2005 the embankment was excavated to install a sewage collector (see Fig. 3a and Fig. 3b). Although the ditch for the collector had been filled up with sand and gravel, the soil was neither compacted nor consolidated, and therefore a kind of "drain" was formed. Negative temperatures in December 2010 and January 2011 led to freezing in the subsurface layer, which prevented the outflow of November precipitation from 


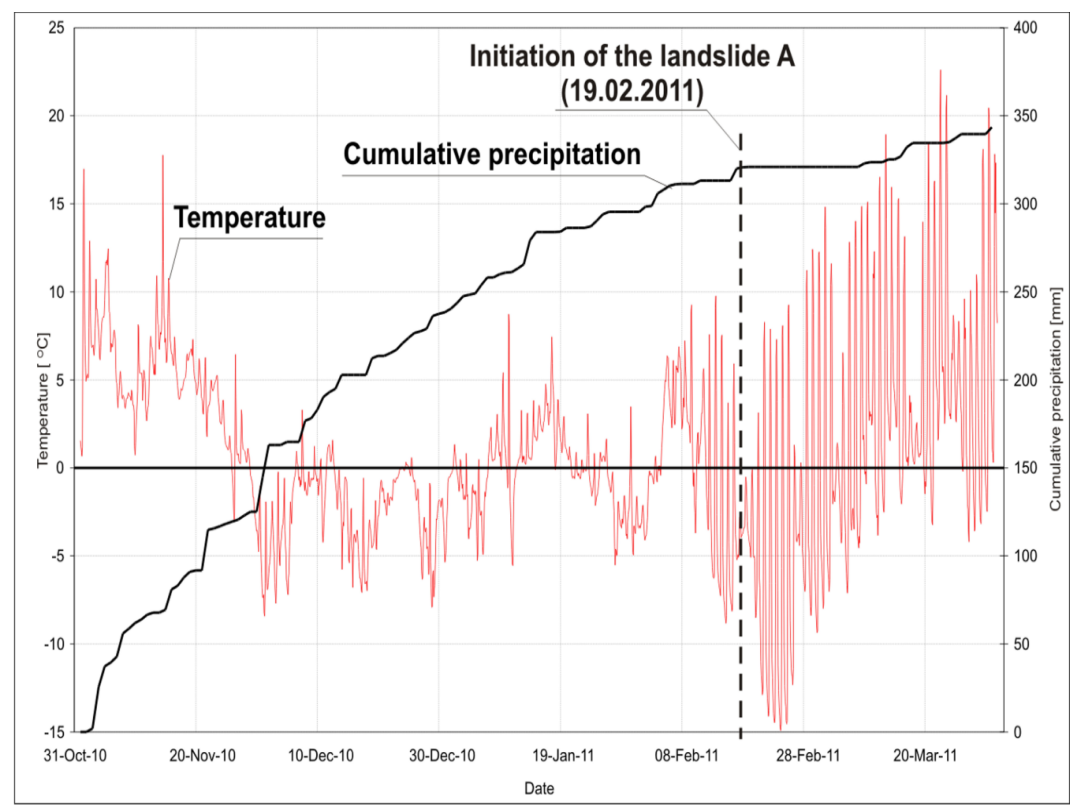

Fig. 7. Cumulative precipitation and temperatures from 1 November 2010 to the end of April 2011

the slope. Moreover, snowfall, especially intensive in December, when temperatures were negative, resulted in a thick snow cover.

With temperature increase in February, the ice-bound water from the November rainfall was released and additionally augmented by snow melt-water. As a result, the soil became highly saturated, which initiated slope deformations. First cracks at the embankment crest made it possible for water to penetrate freely into deeper parts of the slope.

\section{Conclusions}

Detailed analysis of the landslide development from its beginning until the final extensive deformations, combined with the observation of the precipitation-temperature pattern in the preceding 3-4 months, made it possible to reconstruct the landslide process and to identify its causes. The primary passive cause (predisposing factor) typically resulted from the geology of the mass (loose soils underlain by cohesive soils) and from its geomorphology (steep inclination of the embankment surface). However, the fundamental triggering factor for the sliding movement was water accumulated in and then released from the slope mass. In the period preceding the landslide, meteorological conditions were very adverse. Melt-water and water stored earlier in and under the frozen subsurface saturated the clay layer and resulted in the sliding movement along that layer. This explanation has been confirmed by observations of similar behaviour of landslide slopes located in the vicinity and in the Vistula valley (Banach 
et al 2013). The analysis of a slope in the Carpathians has distinctly shown the influence of the depth of the underground water table on the stability of the slope (Zabuski and Przewłócki 2019).

The analysis of the landslide case considered in this paper has proved that the explanation of a landslide may sometimes require a deeper analysis of atmospheric phenomena occurring long before its initiation. And last but not least, harmful human activity should be also taken into account.

\section{References}

Banach M., Kaczmarek H., Tyszkowski S. (2013) Development of landslides in shore zones of water reservoirs, on an example of the central landslide at Dobrzyń-on-the-Vistula, Włocławek Reservoir, Przeglad Geograficzny, 85/3, 397-415 (in Polish).

Bernardie S., Desramaut N., Malet J.-P, Gourlay M., Grandjean G. (2015) Prediction of changes in landslide rates induced by rainfall, Landslides, 12, 481-494.

Berry, K., Lauer, R., Miller, A., Olson, S. (2004) Landslide at a Bridge Abutment in St. Louis, Missouri, Geotechnical Engineering for Transportation Projects, 479-487.

Bromhead E. D, Ibsen M. L. (2007) An Overview of Landslide Problems in British Isles, with Reference to Geology, Geography and Conservation, [in:]Sassa K., Fukuoka F., Wang G., (eds.), Progress in Landslide Science, Springer Verlag, Berlin-Heidelberg.

Chirica, A., Galer, M. (1998) Stability Analysis Corresponding to a New Bridge Abutments, Proceedings of 4th International Conference on Case Histories in Geotechnical Engineering, St. Louis, USA, 1031-1036.

Cruden D. M., Varnes D.J. (1996) Landslides Types and Processes, [in:] Turner A. K., Schuster R. (eds.), Landslides: Investigations and Mitigation, Transportation Research Board, NRC Washington DC Special Report 247, 36-75.

Kulczykowski M., Zabuski L., Mrozek T., Laskowicz I., Świdziński W. (2014) Stabilization of the Landslide in the Brda River Scarp at the Abutment of the Historical Bridge of the Narrow-Gauge Railway (Koronowo, Poland), IAEG XII Congress, Engineering Geology for Society and Territory, Vol. 8: Preservation of Cultural Heritage, 15-19 September 2014, Torino, Italy, Springer, 381-385.

Listkowska H. (1988) Explanations for the detailed geological map of Poland in the scale of 1:50 000, sheet Koronowo), Wydawnictwa Geologiczne, Warszawa (in Polish).

Słowiński M., Błaszkiewicz M., Brauer A., Noryśkiewicz B., Ott F., Tyszkowski S. (2015) The role of melting dead ice on landscape transformation in the early Holocene in Tuchola Pinewoods, North Poland, Quaternary International, 388, 64-75.

Varnes D. J. (1978) Slope movement types and processes., [in:] Schuster R, Krizek R (eds.), Landslides - Analysis and Control, Transportation Research Board, NRC Washington, D.C., Special Report 176, 12-33.

Vassallo R., Grimaldi G. M., Di Maio C. (2015) Pore water pressures induced by historical rain series in a clayey landslide: 3D modelling, Landslides, 12, 731-744.

Zabuski L., Świdziński W., Kulczykowski M., Mrozek T., Laskowicz I. (2015) Monitoring of landslides in the Brda river valley in Koronowo (Polish Lowlands), Environmental Earth Sciences, 73, 8609-8619.

Zabuski L., Świdziński W., Kulczykowski M. (2013) Landslide in a scarp at the abutment of the narrow-gauge railway bridge in Koronowo near Bydgoszcz, Proceedings of XXVI Scientific-Technical Conference on Civil Engineering Disasters, 21-24.05.2013, Międzyzdroje, 451-458 (in Polish). 
Zabuski L., Świdziński W., Kulczykowski M. (2011) Geotechnical report on the causes of a landslide development on a railway embankment and the landslide effect on the stability of the right bank of the narrow-gauge railway in Koronowo, with the concept of the embankment protection, Report of Institute of Hydro-Engineering P.A.S., Gdańsk, Poland (in Polish).

Zabuski L. Przewłócki J. (2019) Stability and stabilization analysis of a landslide slope on the railway in Świnna Poręba (Poland), Inżynieria Morska i Geotechnika, 3, 136-142 (in Polish). 